\title{
Car Insurance Plans Could Make a Society Safer
}

\author{
Mohammad Zand, Amir Samimi*, Khashayar Khavarian \\ Civil Engineering Department, Sharif University of Technology, Tehran, Iran \\ Email: *asamimi@sharif.edu
}

How to cite this paper: Zand, M., Samimi, A. and Khavarian, K. (2016) Car Insurance Plans Could Make a Society Safer. Journai of Geoscience and Environment Protection, 4, 22-36.

http://dx.doi.org/10.4236/gep.2016.412002

Received: September 10, 2016

Accepted: November 28, 2016

Published: December 1, 2016

Copyright $\odot 2016$ by authors and Scientific Research Publishing Inc. This work is licensed under the Creative Commons Attribution International License (CC BY 4.0).

http://creativecommons.org/licenses/by/4.0/

\begin{abstract}
Insurance companies do not differentiate their customers based on their driving behavior in Iran that leads to reckless driving and thereby imposes significant costs to the society. We provided a model that can predict effects of different policies and discounts on market share of insurance companies. The usage of model has been tested in Tehran insurance market and the results provided showed that people would consider changing their insurance plans based on discounts and costs. Further, the first movers (i.e. the insurance companies that offer the discounts first) would absorb safer drivers and thereby stand in a superior financial position. This could significantly change the dynamics and the role of major players in the insurance market.
\end{abstract}

\section{Keywords}

Premium Policies, Stated Preferences, Discrete Choice

\section{Introduction}

Drivers who are more exposed to traffic accidents are not differentiated by insurance companies in Iran [1]. For example, if someone does not use her car at all, she should pay to buy the insurance for next year as much as the person who has drove his/her car for several kilometers last year and has not used any insurance service in that year. This way of treating insurance costumers has many flaws in different aspects. One flaw is the insurance company not using the potential of drivers to make more money. Although it should not be the main reason why the insurance companies would like to change the way they price their services, it can be a good reason to consider other pricing options more accurately. Another flaw is that insurance companies do not charge based upon the vehicle use, and thus those who tend to drive less frequently are actually subsidizing the insurance cost for frequent-drivers [2]. As everybody knows, more cars traveling, more accidents are likely to happen [3]. Besides driving more, acting carelessly or reck- 
lessly when driving would make accidents even more probable. As a result, this imposes a general cost on society. General cost of an accident imposed by proportion of people should not be paid by all the society. At least part of it must be paid by those drivers who are acting in an improper manner [2]. The other flaw of this type of insurance pricing is that it does not have any share in transportation demand management. One way to manage traffic and avoid the congestion is increasing the price of personal vehicle usage directly or indirectly [4]. One indirect way to increase the personal cost of vehicles is to increase the insurance price in proportion with driving kilometer. As mentioned before, the current type of insurance pricing strategies are not in a way that would make people consider not using their vehicles more often.

Other insurance strategies which have been under research act differently. Those strategies try to consider issues like the vehicle-kilometer when selling the insurance. The mentioned strategy which can be called simply mileage or kilometerage strategy is a simple modification which can lead to less car usage if implemented correctly. The only difficulty in charging the insurance according to mileage or kilometerage is the implementation problem. If it was not for the turning back odometers, the mileage in each year can easily be recorded by the insurance company to price the new insurance [2].

The other type of insurance strategy is based on the recorded speed profile of the vehicle. In this type of insurance promotion strategy, the driver would get discount if he/she has drove above the speed limit less than a specific amount of kilometers. Although driving above the speed limit can cause accidents, this type of promotion can decrease the number of people driving unsafe with high speeds [4].

The advantages of these types of insurance strategies can be concluded as:

- Increasing accuracy of insurance price calculation.

- Increasing safety due to drivers behavior change.

- Decreasing total vehicle-kilometers and as a result decrease in: congestion, road maintenance cost, fuel usage and pollution emission.

- Developing a tool which would make reckless drivers to pay for the incurred cost of their improper behavior.

- Changing the fixed cost of personal vehicles to variable and operational cost and as a result reduction of the personal vehicle usage.

The disadvantages or difficulties to implement these types of insurance strategies are:

- Requirement of developing new methods to estimate the risk of different driver's behavior to estimate the promotion and price of the insurance services each year.

- Need to install new instruments on vehicles in some strategies like speed based promotion.

- Difficulty in predicting the value of insurance for next year before ending the current contract.

- Possible opposition in some institutions and agencies to implement these scenarios.

Respecting all the mentioned advantages and current flaws, there remains an important question to answer. The question which is the main reason of conducting this research is to what extent it would be accepted by the public and how much they would 
prefer it to change their insurance plan. Although all implementation issues are important, it is vital to make sure that people would change their insurance plan willingly so that companies implementing these types of insurance plans would not lose their market share.

The mentioned question and even the implementation issues have been studied and different researches have been done but the results can't be used directly in Iran. As a result of different cultural issues and driving situations or even different laws, it is recommended to conduct a study like this in order to investigate the attitude of people toward insurance plane change.

In following sections of this paper, short history of conducted researches and the results would be presented. Then the methodology and data gathering process used in this research would be depicted and finally the conclusions would be made.

\section{Literature Review}

The insurance plans based on the distance were proposed by Vickrey in 1968. Vickrey in his paper demonstrates the cost of traffic accidents in the United States between 8 to 12 billion dollars a year and depicted that the accidents' cost are being paid proportionally by the government which is the same as giving subsidies to those travelling by car. He shows that paying premium is included in fixed cost of a car and it does not have any effect on choices like letting young people to drive or taking bus instead of car. He excavates ways of distance-based premium promotions despite the fact the odometers can be reset. He presents that premium can be based on tires or gasoline instead of distances itself [2]. Although the proposed ways are mostly to make implementation simpler, but flaws and problems through implementing are beyond our study scope.

After Vickrey, Wenzel tried to examine and develop the proposed insurance strategies. Wenzel demonstrates that with "Pay as You Drive (PAYD)" premium strategy, drivers would pay part of their vehicle insurance as gasoline surcharge. In Wenzel Report, some of qualitative issues surrounding adoption of PAYD and other policies that would convert the fixed cost to variable cost of driving are discussed. He separates two types of objectives and examines the premium policies effects separately. The objectives in Wenzel study are: 1) objectives related to auto-insurance reform, 2) objectives related to vehicle usage effects including $\mathrm{CO}_{2}$ emission and vehicle miles traveled. As mentioned in that study there already exist two types of insurance in the United States that are used to pay the expenses incurred in an auto accident, first party and third party coverage which are mandatory in different states [5]. Wenzel suggests that the currently driving teens which are mostly uninsured or on their parents' policy can be discouraged by properly designed PAYD system. The importance of premium policy effects on objectives related to vehicle usage about teenagers is that several studies have shown them as one of the riskiest class of drivers [5].

The reviewed researches have not explicitly studied the effect of PAYD on emission but they have brought some insight about it. As an instance, the American Council for an Energy-Efficient Economy has modeled several insurance policies including PAYD 
and with some assumptions about insurance charges of gasoline, estimated that vehicle miles travelled would be reduced by 5.1 percent if all the states have adopted the PAYD by 2010 . They also estimated that it would result a 12 percent reduction in greenhouse gas emission [5].

Another study which was conducted by Edlin, tried to verify the relation between travelled distance of vehicles and probability of accident occurrence. After verifying the relation using mathematical formulations, the expected benefits of distance-based insurance policies were estimated. The estimated benefits for insured accident costs are 9.8 to 12.7 billion dollars and when the uninsured accidents are considered too, the benefits would raise to 25 billion dollars. At last, it is concluded that one primary reason that insurance companies has not change their premium policy to distance-based is the cost of implementing it, since most of the benefits are all external [3]

Another study which was intended to examine two proposed premium policies effects on driving issues was conducted by Hultkrantz et al. [4]. They were trying to internalize the external cost of accidents and driving carelessly. In order to do that they evaluate the decrease in car usage and driving above the speed limit after introducing the premium policies based on travelled distance and speed limit violation. They propose two different premium policies which are combination of two types of taxes: 1) tax on driving and tax on speeding which means tax on vehicle usage and the speeding tickets, 2) a combination of "pay as you speed (PAYS)" and tax on vehicle insurance. Hultkrantz et al. used Sweden data and concluded that taxes on fuel have internalized the vehicle usage cost in non-congested areas but the speeding tickets were unable to do so. He concluded that speed limit violation premium policy instead of current insurance strategies would lead to more personal vehicle usage but less speed limit violation. In contrast with PAYS full internalization is feasible [4].

Another research by Litman for Victoria Transport Policy Institute compares different types of distance-based insurance policies including:

- Mileage Rate Factor,

- Pay at the Pump,

- Mandatory insurance pricing per mile of travel,

- Insurance and registration fees based on the travel distance,

- Choosing between insurance per mile or vehicle-year premiums,

- GPS-based pricing.

Litman uses different measures to evaluate the policies including actuarial accuracy; implementation costs; travel impacts; road safety; energy and emission; congestion and facility cost savings; consumer impact; equity; affordability; economic efficiency, productivity and development; and public acceptability.

In public acceptability measure, Litman summarizes that there is likely to be strong support for optional distance-based insurance. In contrary the public response to mandatory distance-based insurance is mixed. People support reforms increasing equity and offering savings but hardly believe it does not raise the costs for disadvantaged groups. He concludes that mileage rate factor is not acceptable because of unverified 
mileage data but the Pay at the pump policy is the least popular option because it is like a new fuel tax. At last he concludes that there is no evidence that consumers have a strong preference for fixed price insurance [6].

After analyzing each option based on the measures, best score is shown by 3 and worst score is shown by -3 . The summation of scores in each option is then used to make conclusions. This study concludes that the most effective Distance-Based pricing method is per-mile premiums and per-minutes premium as a mandatory insurance [6].

A more recent study is conducted on privacy issues and compensating the freedom lost due to internet of things with monetary values. Since implementing the premium policies are easier through connected cars technology using GPS sensors, people willingness to change their privacy as an interest with discounts in insurance policies must be estimated. In order to check if people would like to substitute their privacy with insurance discounts, a study by Derikx et al. [7] used a logit model to investigate that. Sixty people were surveyed in the study and the sample was representative of the target population. Derikx et al. [7] presented two levels of privacy harm (no harm and harm) and three levels of insurance discount respecting the monthly amount of car insurance which is regular in the Netherlands. They built a log it model in order to estimate the proper value of discounts and concluded that in some levels privacy issues can be compensated by insurance discounts. Another finding based on the model and data of this study is the more value consumers attribute to privacy of action than space and location [7].

Another study done by Zhao and Zhou [8] is to investigate the frequency of claims and the class of insurance in order to use good-bad premiums system. This system, in general, changes the insurance premium based on the history of the insured behavior. Although the problem which researchers dealt with is purely methodological, the effect of previous actions taking into account to change the insurance premium in a systematic manner, like what they proposed in their study, can be used in implementing these policies.

A research which was intended to mine the big data of insurance in order to understand which insurance policy people would choose was conducted by Alshamsi [9]. She shows that Random Forest method can be used to find the answer of her study, but the proposed or available insurance policy options are not depicted at all [9].

To summarize the studies about distance-based insurances, Table 1 is presented.

As it can be seen, some researchers are restricted to the results after implementing these types of insurance policies. The evaluated results are like car usage reduction or decrease in speed violation. Others are providing methods to use the gathered data of insurance companies for making better decisions toward different policies. The remained question which is not directly answered in these studies is whether or not people would use the distance-based insurance policy instead of fixed insurance premium each year, and if they do so, how much it would be affected by prices or promotions? The main question of this research is the type of questions which should be answered in different countries and cultures separately in order to have the best result. In 
Table 1. Summary of reviewed studies.

\begin{tabular}{|c|c|c|c|}
\hline Researchers & Year & Subject & Summary of Findings \\
\hline Vickrey & 1968 & $\begin{array}{l}\text { Automobile accidents, tort law, } \\
\text { externalities, and insurance: an } \\
\text { economist's critique }\end{array}$ & $\begin{array}{l}\text { Proposing different insurance types to } \\
\text { solve the short comes of current } \\
\text { premium policies, Such as PAYD fuel } \\
\text { taxes }\end{array}$ \\
\hline Wenzel & 1995 & $\begin{array}{l}\text { Analysis of national } \\
\text { pay-as-you-drive insurance } \\
\text { systems and other variable driving } \\
\text { charges }\end{array}$ & $\begin{array}{l}\text { Using PAYD or similar insurance } \\
\text { strategies would decrease the effects of } \\
\text { vehicle ownership on environment }\end{array}$ \\
\hline Edlin & 1999 & $\begin{array}{l}\text { Per-mile premiums for auto } \\
\text { insurance }\end{array}$ & $\begin{array}{l}\text { There is social benefit in using the } \\
\text { distance-based insurance premium as } \\
\text { much as } 25 \text { billion dollars }\end{array}$ \\
\hline $\begin{array}{l}\text { Hultkrantz, } \\
\text { Nilsson, } \\
\text { \& Arvidsson }\end{array}$ & 2012 & $\begin{array}{l}\text { Voluntary internalization of } \\
\text { speeding externalities with vehicle } \\
\text { insurance }\end{array}$ & $\begin{array}{l}\text { Pays as you speed insurance policy } \\
\text { would lead to less vehicle usage but do } \\
\text { not decrease speed violation }\end{array}$ \\
\hline Litman & 2012 & $\begin{array}{l}\text { Distance-Based Vehicle Insurance } \\
\text { as a TDM Strategy }\end{array}$ & $\begin{array}{l}\text { The most effective Distance-based } \\
\text { pricing method is Per-mile Premiums } \\
\text { and per-minutes premium as a } \\
\text { mandatory insurance }\end{array}$ \\
\hline Derikx & 2016 & $\begin{array}{l}\text { Privacy concerns for insurance of } \\
\text { connected cars }\end{array}$ & $\begin{array}{l}\text { People would substitute their privacy } \\
\text { with monetary discounts in behavior } \\
\text { insurance policies. They perceive action } \\
\text { privacy more valuable }\end{array}$ \\
\hline Zhao \& Zhou & 2014 & $\begin{array}{l}\text { Copula-based dependence between } \\
\text { frequency and class in car } \\
\text { insurance with excess zeros }\end{array}$ & $\begin{array}{l}\text { Providing a Copula distribution to } \\
\text { track the dependence between claim } \\
\text { frequency and class in car insurance to } \\
\text { find a systematic way to change the } \\
\text { premium insurances }\end{array}$ \\
\hline Alshamsi & 2014 & $\begin{array}{l}\text { Predicting car insurance policies } \\
\text { using random forest }\end{array}$ & $\begin{array}{l}\text { Checks the random forest method for } \\
\text { insurance data mining to predict the } \\
\text { insurance choice of people }\end{array}$ \\
\hline
\end{tabular}

following chapters of this research the way to find an answer for the mentioned question and the answer itself would be discussed.

\section{Methodology}

As said in previous sections, the question of interest in this research is the reluctance or willingness of people to use the distance-based insurance premium policies respecting the cost or method of price calculation. To analyze this problem we should find a way to ask people their opinion about the probable scenarios of insurance strategies. This problem is usually solved using "stated preference" or "SP" surveys.

The stated preference is a way of understanding the opinion of people about some unreal or not present options which are likely to happen and somehow it is against the "revealed preference" or in short "RP". In SP the researcher demonstrates a situation for the respondent and asks his/her opinions toward different options but in RP the situation is real and currently happening, the opinion toward this situation is captured from 
the actions of people. As an instance, in order to find out people willingness to use bus services, if the public service exists, then the share of people using it would be a measure of willingness and the method of study is revealed preference. If public service is not available, then the researcher should depict the public service options for the respondents and ask if they would use that or not. The second method is called the stated preference.

In our study, we used the SP method in order to find out the willingness of people toward using distance-based insurance strategies. In order to do that, four scenarios in addition to current vehicle-year strategy, is used:

- Distance-based Discount

- Distance-based and Law Obedience Discount

- Distance-based Coverage

- Distance-based Coverage and Law Obedience Discount

In the distance-based discount scenario, same as current premium strategy, the insurance cost is paid in full. After one year, using the additional odometer gathered data, the vehicle would be classified in one of the following groups: 1) less than 5 thousand kilometers, 2) between 5 to 10 thousand kilometers, 3) between 10 to 15 thousand kilometers and 4) more than 15 thousand kilometers. If the vehicle is not placed in group number 4 , then the premium discounts can be used by the owner. The premium discounts are presented later in this section.

In the second scenario which is distance-based and law obedience discount, as the first scenario, the full insurance fee is paid up front. This scenario needs some tracking device to be installed on cars in order to gather speed data as a measure of law obedience and speed violation tracking. The vehicle would be classified in three categories in addition to traveled distance categories such as:

- Fully Obedient

- Some Obedient

- Not Obedient

As a result, this scenario partitions the people using it to 12 different categories. The premium discounts related to each group would be depicted later in this section.

In the third scenario which is distance-based coverage policy, the premium is not for a complete year. The customer buys the desired package (one of the 5,10 and 15 thousand kilometers threshold packages) and until driving that much, the vehicle is under insurance; after reaching the kilometer threshold of their insurance package, the customer would buy another insurance package. In order to calculate the kilometerage of vehicle, an additional odometer is connected to vehicle.

The last scenario is same as the third one with one difference. In this scenario, there should be a tracking device installed on the vehicle to track the quality of law obedience. To summarize the options Table 2 is presented.

As was mentioned in the preceding sections, we are trying to investigate the most effective discount values. To put it simpler, the value of discounts and prices that would cause more people to use the option. In order to do that, three levels are defined for 
each option and prices and discounts are presented in these levels. The cost and discount values of the proposed options are summarized in Table 3 and Table 4.

The values are mainly derived from the current situation and the proposed undiscounted groups. As an instance, the 15 thousand kilometer is the threshold of not getting discounts for distance group 4 . The cost of each kilometer more than this value can be calculated as current premium price ( 600 thousand Tomans) divided by 15 thousand kilometers, which is 40 Tomans. As it can be seen in Table 3 the cost values of each kilometer is $30,40,50$ Tomans in each level.

The next part is to ask people about the proposed insurance scenarios. There are several surveying methods available which all has advantages and disadvantages over each other. After analyzing the affordability and reliance of survey methods for our problem we concluded that the best way is to ask in-person and the best place to ask about the insurance policy are vehicle inspection centers. The advantages and disadvantages of other places are summarized in Table 5.

Table 2. Summary of insurance policies.

\begin{tabular}{|c|c|c|c|c|c|}
\hline Characteristics & $\begin{array}{c}\text { Do } \\
\text { nothing }\end{array}$ & $\begin{array}{l}\text { Distance-based } \\
\text { Discount }\end{array}$ & $\begin{array}{c}\text { Distance-based } \\
\text { Law and Obedient } \\
\text { Discount }\end{array}$ & $\begin{array}{l}\text { Distance-based } \\
\text { Coverage }\end{array}$ & $\begin{array}{c}\text { Distance-based } \\
\text { Coverage and Law } \\
\text { Obedient Discount }\end{array}$ \\
\hline $\begin{array}{l}\text { Installation } \\
\text { Cost }\end{array}$ & 0 & 100 & 300 & 100 & 300 \\
\hline $\begin{array}{l}\text { Consumption } \\
\text { Flexibility }\end{array}$ & no & yes & yes & yes & yes \\
\hline Privacy Issues & no & no & yes & no & yes \\
\hline $\begin{array}{l}\text { Other Special } \\
\text { Usages }\end{array}$ & no & no & yes & no & yes \\
\hline
\end{tabular}

Table 3. Summary of costs in policies (thousands tomans).

\begin{tabular}{cccc}
\hline Options & Level 1 & Level 2 & Level 3 \\
\hline One year Coverage & 0 & 600 & - \\
5 thousands kilometers Coverage & 150 & 200 & 250 \\
10 thousands kilometers Coverage & 300 & 400 & 600 \\
15 thousands kilometers Coverage & 450 & 600 & 750 \\
Equipment Installation Cost & 0 & 100 & 300 \\
\hline
\end{tabular}

Table 4. Summary of discounts in policies (thousands tomans).

\begin{tabular}{cccc}
\hline Options & Level 1 & Level 2 & Level 3 \\
\hline Distance-based group 3 & 30 & 40 & 60 \\
Distance-based group 2 & 60 & 80 & 120 \\
Distance-based group 1 & 90 & 120 & 180 \\
Some Obedient & 30 & 60 & 90 \\
Fully Obedient & 60 & 120 & 180 \\
\hline
\end{tabular}


There are 10 vehicle inspection centers in Tehran which are mostly spread in outer ring of the city.

Before gathering data, two pilot studies were done and two main issues were solved about the survey:

- The survey should be in color.

- The survey should give information in written format, no special graphic is needed.

After all, the survey was done in 10 - 20 of March at 2012. 980 of people were asked to fill the questioner but 47 people did not fill the form out. After gathering the data, the usable number of forms was 848. Some data characteristics are presented in Table 6.

Some primary outcomes can be presented in this Stage of research:

Table 5. Advantages and disadvantages of surveying places.

\begin{tabular}{|c|c|c|}
\hline Places & Advantages & Disadvantages \\
\hline Schools & $\begin{array}{l}\text { Geographic extent } \\
\text { Different type of people availability } \\
\text { Low cost } \\
\text { Easy trust gain } \\
\text { High number of observations }\end{array}$ & $\begin{array}{l}\text { Cumbersome topic for students } \\
\text { Hard permission gathering process }\end{array}$ \\
\hline $\begin{array}{c}\text { Insurance } \\
\text { Payment centers }\end{array}$ & $\begin{array}{l}\text { Enough time to ask } \\
\text { People mind readiness } \\
\text { Trust gain }\end{array}$ & $\begin{array}{l}\text { Uninsured people unavailable } \\
\text { Impatient people }\end{array}$ \\
\hline Universities & $\begin{array}{l}\text { Availability of students } \\
\text { Enough time to ask } \\
\text { Low cost } \\
\text { Easy permission gathering process }\end{array}$ & $\begin{array}{l}\text { Sample bias (restricted to educated } \\
\text { people) }\end{array}$ \\
\hline Fuel Station & $\begin{array}{l}\text { Enough time to ask } \\
\text { Car owners availability }\end{array}$ & $\begin{array}{l}\text { Hard trust gain } \\
\text { Bad distribution respecting distance }\end{array}$ \\
\hline $\begin{array}{l}\text { Vehicle inspection } \\
\text { centers }\end{array}$ & $\begin{array}{l}\text { Enough time to ask } \\
\text { Easy trust gain } \\
\text { Geographic extent }\end{array}$ & Uninsured people unavailable \\
\hline
\end{tabular}

Table 6. Advantages and disadvantages of surveying places.

\begin{tabular}{cl}
\hline Variable & Possible Outcome Shares \\
Gender & Men: $89 \%$, Women: $11 \%$ \\
& 18 to $25: 11 \%$ \\
& 25 to $35: 39 \%$ \\
& 35 to $55: 37 \%$ \\
& more that $55: 13 \%$ \\
& Lower than Diploma: $9 \%$ \\
& Diploma and Associate Degree: $37 \%$ \\
& Bachelor of Science: $37 \%$ \\
& Master and Higher: $17 \%$ \\
& Class I (Pride, Peykan \& older than 30$): 34 \%$ \\
& Class II (Peugeot, Samand, Rio, Other Domestic Vehicles): $56 \%$ \\
& Class III (Foreign Vehicles): $10 \%$ \\
Car Class &
\end{tabular}


- 73 percent of respondents have chosen at least one of the distance-based premium strategies.

- 84 percent said they would change their insurance provider if another well-known insurance company provides the distance-based insurance.

After surveying and primary analyses, we tried to develop a model to estimate the preferences of people toward different insurance policies. The dependent variable is if people use the new insurance policies mentioned before or not. As seen, the dependent variable value is zero when people won't use the new insurance policies and it gets value of one when the person who is making decision about his insurance policy for personal vehicle, would use one of the proposed policy insurances. Therefore usage of discrete choice models to investigate the mentioned problem is the best way to deal with it.

There are different structures which can be used to model discrete choice events. One useful and easy-to-use structure is the logit model. In this model the utility of choices is a linear combination of different factors which affect the utility. Usually the utility functions are not complete. It means we are not able to consider all the affecting factors in utility. In order to solve this problem a random term is added to the utility function which follows the Gumbel distribution. As a result, the random part may or may not have correlation in different choices. To overcome this possibility in this research we use two models, simple logit and nested logit. The Nested logit has a slight difference with the simple logit model to overcome the correlation problem of utility choice models. It partitions choices to subsets (nests) which have common properties, e.g. the random parts do not have correlation in same nests. The nests choices have two characteristics [10].

- For any two alternatives that are in the same nest, the ratio of probabilities is independent of the attributes or existence of all other alternatives.

- For any two alternatives in different nests, the ratio of probabilities can depend on the attributes of other alternatives in the two nests.

In simple logit all choices are in one nest, e.g. the ratio of probabilities is independent of the attributes or existence of all other alternatives. The probability of selecting one choice is derived using Equation (1) in simple logit and by Equation (2) in nested logit [10].

$$
P_{n i}=\frac{\exp \left(\frac{\left(V\left(x_{n i}\right)+e_{n i}\right)}{\lambda_{\mathrm{k}}}\right)\left(\sum_{\mathrm{j} \in \mathrm{B}_{\mathrm{k}}}\left(\exp \frac{\exp \left(V\left(x_{n i}\right)+e_{n i}\right)}{\sum_{i} \exp \left(V\left(x_{n i}\right)+e_{n i}\right)}\right)\right)^{\lambda_{\mathrm{k}}-1}}{\sum_{\mathrm{l}=1}^{\mathrm{k}}\left(\sum_{\epsilon}\left(\exp \frac{\left(V\left(x_{n j}\right)+e_{n j}\right)}{\lambda_{\mathrm{l}}}\right)\right)^{\lambda_{1}}}
$$

The definitions of variables in above equations are as below:

$P_{n i}$ : Probability of choosing alternative $i$ for person $n$.

$x_{n i}$ : Observed vector of affecting factors for alternative $i$ and person $n$. 
$V\left(x_{n i}\right)$ : Linear utility function of the alternatives.

$e_{n i}$ : Random variable (error term or unobserved factors) of the utility.

$\lambda_{1}$ : The Inclusive Value, e.g. measure of the degree of independence in unobserved utility among the alternatives of nest $\mathrm{L}$.

\section{$B_{l}$ : Nest of L.}

In this research the Nested logit model is formed based on privacy issues. Since "Distance-based Law Obedient Discount" and "Distance-based Coverage and Law Obedient Discount" have privacy issues, they would be in same nest and the rest of insurance policies, including the do nothing option, would be in the other nest. The model estimation results are presented in Table 7.

As it comes to mind, people who have more annual traveled distance, would less tend to buy any distance-based insurance, as a result the coefficient of annual traveled distance is positive in both models. The models depict that people with class one cars are not interested in distance-based discount and also having more than one car or being in class two has positive effect on distance-based premium desire of drivers.

\section{Discussion}

The models in preceding section are used to evaluate the effect of variables on people choices. In order to do that we used a dimension-less index derived from the model which is called elasticity. Elasticity is the percentage change in value of a function due to one percentage increase in a variable. The calculated elasticities are presented in $\mathrm{Ta}$ ble 8 and Table 9 . The binary variables elasticity is the difference between the function values if the variable is one or zero.

Table 7. Model estimation results.

\begin{tabular}{clcc}
\hline \multirow{2}{*}{ Alternative } & \multicolumn{1}{c}{ Variables and Definitions } & Simple Logit & Nested Logit \\
\hline \multirow{2}{*}{ Do Nothing } & To have third Person Insurance (1) or not $(0)^{*}$ & $-0.302^{* * *}$ & $-0.472^{* * *}$ \\
& Average of Annual Traveled Distance & $0.008^{* *}$ & $0.013^{*}$ \\
& Constant & $4.364^{* * *}$ & $4.534^{* * *}$ \\
Distance-based & Total Cost & $-0.009^{* * *}$ & $-0.009^{* * *}$ \\
Discount & Car Class I (The car is in class I (1) or not $(0))^{*}$ & $-0.381^{* * *}$ & $-0.427^{* * *}$ \\
& Car ownership (more than one car $(1)$ else $(0))^{*}$ & $0.478^{* * *}$ & $0.599^{* * *}$ \\
Distance-based and & Constant & $-1.388^{* * *}$ & $-1.779^{* * *}$ \\
Law Obedient & Maximum discount of the alternative & $0.004^{* * *}$ & $0.005^{* * *}$ \\
Discount & Car Class II (The car is in class II (1) or not $(0))^{*}$ & $0.338^{* * *}$ & $0.391^{* * *}$ \\
& Constant & & \\
Distance-based & Third class of age (If decision maker is between 35 to & $0.706^{* * *}$ & $0.640^{* * *}$ \\
Coverage & 55 years old (1) else (0)) & $0.357^{* * *}$ & $0.474^{* * *}$ \\
& Total Cost & $-0.002^{* * *}$ & $0.002^{* * *}$ \\
Distance-based & Constant & & \\
Coverage and Law & Total Cost & $1.712^{* * *}$ & $1.566^{* * *}$ \\
Obedient Discount & & $-0.002^{* * *}$ & $-0.002^{* * *}$ \\
\hline
\end{tabular}

${ }^{*}$ Binary Variables, ${ }^{*} 90$ percentile confidence interval, ${ }^{* *} 95$ percentile confidence interval, ${ }^{* *} 99$ percentile confidence interval. 
Table 8. Elasticities estimation results.

\begin{tabular}{|c|c|c|c|c|c|c|c|}
\hline \multirow{2}{*}{ Variable } & \multirow{2}{*}{ Alternative } & \multicolumn{2}{|c|}{ Do Nothing } & \multicolumn{2}{|c|}{$\begin{array}{l}\text { Distance-based } \\
\text { Discount }\end{array}$} & \multicolumn{2}{|c|}{$\begin{array}{l}\text { Distance-based } \\
\text { Coverage }\end{array}$} \\
\hline & & Simple & Nested & Simple & Nested & Simple & Nested \\
\hline $\begin{array}{l}\text { Third Person } \\
\text { Insurance }\end{array}$ & Do Nothing & -0.127 & -0.142 & 0.055 & 0.156 & 0.055 & 0.156 \\
\hline $\begin{array}{c}\text { Average of } \\
\text { Annual Distance }\end{array}$ & Do Nothing & 0.100 & 0.101 & -0.060 & -0.164 & -0.06 & -0.164 \\
\hline \multirow{4}{*}{ Total Cost } & Distance-based Discount & 0.414 & 0.736 & -5.546 & -5.434 & 0.414 & 0.736 \\
\hline & $\begin{array}{l}\text { Distance-based } \\
\text { Coverage }\end{array}$ & 0.157 & 0.275 & 0.157 & 0.275 & -2.404 & -2.322 \\
\hline & Distance-based & & & & & & \\
\hline & $\begin{array}{l}\text { Coverage \& Law } \\
\text { Obedient Discount }\end{array}$ & 0.355 & 0.218 & 0.355 & 0.218 & 0.355 & 0.218 \\
\hline Car Class I & $\begin{array}{l}\text { Distance-based } \\
\text { Discount }\end{array}$ & 0.006 & 0.013 & -0.091 & -0.115 & 0.006 & 0.013 \\
\hline Car Ownership & $\begin{array}{l}\text { Distance-based } \\
\text { Discount }\end{array}$ & -0.013 & -0.028 & 0.127 & 0.149 & -0.013 & -0.028 \\
\hline Third class of age & $\begin{array}{l}\text { Distance-based } \\
\text { Coverage }\end{array}$ & -0.014 & -0.034 & -0.014 & -0.034 & 0.118 & 0.145 \\
\hline $\begin{array}{l}\text { Maximum } \\
\text { discount of the } \\
\text { alternative }\end{array}$ & $\begin{array}{l}\text { Distance-based and Law } \\
\text { Obedient Discount }\end{array}$ & -0.410 & -0.310 & -0.410 & -0.310 & -0.410 & -0.310 \\
\hline
\end{tabular}

Table 9. Elasticities estimation results for "law obedient" scenarios.

\begin{tabular}{|c|c|c|c|c|c|}
\hline \multirow[t]{2}{*}{ Variable } & \multirow[t]{2}{*}{ Alternative } & \multicolumn{2}{|c|}{$\begin{array}{l}\text { Distance-based and Law } \\
\text { Obedient Discount }\end{array}$} & \multicolumn{2}{|c|}{$\begin{array}{c}\text { Distance-based Coverage } \\
\text { and Law Obedient } \\
\text { Discount }\end{array}$} \\
\hline & & Simple & Nested & Simple & Nested \\
\hline $\begin{array}{l}\text { Third Person } \\
\text { Insurance }\end{array}$ & Do Nothing & 0.055 & 0.030 & 0.055 & 0.030 \\
\hline $\begin{array}{c}\text { Average of } \\
\text { Annual Distance }\end{array}$ & Do Nothing & -0.060 & -0.033 & -0.060 & -0.033 \\
\hline \multirow{3}{*}{ Total Cost } & $\begin{array}{l}\text { Distance-based } \\
\text { Discount }\end{array}$ & 0.414 & 0.143 & 0.414 & 0.143 \\
\hline & $\begin{array}{l}\text { Distance-based } \\
\text { Coverage }\end{array}$ & 0.157 & 0.053 & 0.157 & 0.053 \\
\hline & $\begin{array}{c}\text { Distance-based } \\
\text { Coverage \& Law } \\
\text { Obedient Discount }\end{array}$ & 0.355 & 0.678 & -2.270 & -1.918 \\
\hline Car Class I & $\begin{array}{l}\text { Distance-based } \\
\text { Discount }\end{array}$ & 0.006 & 0.002 & 0.006 & 0.002 \\
\hline Car Ownership & $\begin{array}{l}\text { Distance-based } \\
\text { Discount }\end{array}$ & -0.013 & -0.006 & -0.013 & -0.006 \\
\hline Third class of age & $\begin{array}{l}\text { Distance-based } \\
\text { Coverage }\end{array}$ & -0.014 & -0.007 & -0.014 & -0.007 \\
\hline $\begin{array}{l}\text { Maximum } \\
\text { discount of the } \\
\text { alternative }\end{array}$ & $\begin{array}{c}\text { Distance-based and } \\
\text { Law Obedient Dis- } \\
\text { count }\end{array}$ & 0.791 & 0.787 & -0.410 & -0.681 \\
\hline
\end{tabular}


Two variables that can be changed by the policy maker are "Total Cost" and the "Maximum Discount of the Alternative". Based on the estimated elasticities, increasing total cost of the distance-based coverage and law obedient discount would lead to increase in share of the other alternatives same as do nothing scenario. The best combination of mentioned decision variables must be calculated using some optimization method based on a specific goal. This problem is beyond scope of this paper.

Using data and elasticities we are able to calculate the change in market share of different insurance companies. In order to calculate the change, we assume that each proposed alternative is only available beside the do nothing scenario.

When the only option beside current scenario is the distance-based discount, using different amount of discounts for the mentioned groups of traveled distances, would result market shares as in Table 10.

When the only available option beside current policy is the distance-based and law obedient discount, using combination of different discounts would result market share as Table 11 .

When the only available option beside current policy is the distance-based coverage, different costs for each coverage package would result market shares as in Table 12.

Table 10. Market share for distance-based discount policy (percentage).

\begin{tabular}{ccccccc}
\hline & \multicolumn{5}{c}{ Discounts for each Group of Traveled Distance (thousand Tomans) } \\
\cline { 2 - 7 } Alternative & 10 & 20 & 30 & 40 & 50 & 60 \\
\hline $\begin{array}{c}\text { Do nothing } \\
\text { Distance-based } \\
\text { Discount }\end{array}$ & 80 & 77 & 74 & 70 & 30 & 63 \\
\hline
\end{tabular}

Table 11. Market share for distance-based and law obedient discount policy.

\begin{tabular}{|c|c|c|c|c|c|c|}
\hline Alternative & \multicolumn{6}{|c|}{ Discounts (thousand Tomans) } \\
\hline Distance-based & 0 & 0 & 0 & 0 & 0 & 20 \\
\hline Law Obedient Discount & 0 & 20 & 40 & 60 & 80 & 20 \\
\hline Alternative & \multicolumn{6}{|c|}{ Share (percentage) } \\
\hline Do nothing & 83 & 79 & 75 & 70 & 65 & 73 \\
\hline $\begin{array}{c}\text { Distance-based \& Law Obedient } \\
\text { Discount }\end{array}$ & 17 & 21 & 25 & 30 & 35 & 27 \\
\hline
\end{tabular}

Table 12. Market share for distance-based coverage policy (percentage).

\begin{tabular}{cccccc}
\hline \multirow{2}{*}{ Alternative } & \multicolumn{5}{c}{ Cost of a 5 thousand kilometers Coverage Package (thousand Tomans) } \\
\cline { 2 - 5 } & 10 & 20 & 30 & 40 & 50 \\
\hline $\begin{array}{c}\text { Do nothing } \\
\begin{array}{c}\text { Distance-based } \\
\text { Coverage }\end{array}\end{array}$ & 55 & 65 & 72 & 22 & 83 \\
\hline
\end{tabular}


When the only available option beside current policy is the distance-based and law obedient discount, using combination of different discounts would result market share as Table 13.

As it can be seen in tables above, the share of some proposed policies are more than a half. As a result if an insurance company proposes this type of insurance policy, people would consider using the new opportunity. It can be an incentive for insurance providers to consider the mentioned policies in this research for future provision.

To propose a discount value for a specific scenario of insurance policy to be applied in future in Tehran, a specific objective should be selected and best scenario must be chosen. The objectives can be personal vehicle usage reduction or personal vehicle usage impacts reduction and so on. The mentioned process is out of the scope of this paper but another rule of thumb can be used instead. The objectives can be changed to maximum usage of the new insurance policy, which have to be proved being the most effective policy for achieving one of the mentioned objectives. Since the most effective policies are not known yet, values for the maximum share of each can be concluded as those which are good to be applied in Tehran. The values are summarized in Table 14.

\section{Conclusions}

To conclude, we provided a model that can predict effects of different policies and discounts on market share of insurance companies. The usage of model has been tested on Tehran insurance market and the results provided showed that people would consider changing their insurance plans based on discounts and costs.

Table 13. Market share for distance-based and law obedient discount policy.

\begin{tabular}{cccccccccc}
\hline Alternative & \multicolumn{7}{c}{ (Thousand Tomans) } \\
\hline $\begin{array}{c}\text { Distance-based Coverage (Costs) } \\
\text { Law Obedient Discount }\end{array}$ & 150 & 200 & 250 & 150 & 200 & 250 & 150 & 200 & 250 \\
Alternative & 30 & 30 & 150 & 60 & 60 & 60 & 90 & 90 & 90 \\
\hline $\begin{array}{c}\text { Do nothing } \\
\begin{array}{c}\text { Distance-based Coverage \& Law } \\
\text { Obedient Discount }\end{array}\end{array}$ & 62 & 70 & 76 & 58 & 67 & 74 & 55 & 64 & 71 \\
\hline
\end{tabular}

Table 14. Costs and discounts for maximum share of new policies.

\begin{tabular}{cccc}
\hline Alternative & $\begin{array}{c}\text { Cost }^{*} \\
\text { (Thousand Tomans) }\end{array}$ & $\begin{array}{c}\text { Discount } \\
\text { (Thousand Tomans) }\end{array}$ & $\begin{array}{c}\text { Share } \\
\text { (percent) }\end{array}$ \\
\hline Distance-based Discount & - & 60 & 37 \\
Distance-based \& Law Obedient Discount & - & 120 & 54 \\
Distance-based Coverage & 10 & - & 45 \\
Distance-based Coverage \& \\
Law Obedient Discount
\end{tabular}

${ }^{*}$ The fixed cost of the equipment is not considered. 
For further investigate in this subject, the following modifications can be made:

- Dynamic survey: in this research due to some restrictions, online or smart surveys are not used. But it would be more convenient to use one of those technologies in order to get more precise answers. As an instance, when one's initial cost is related to the annual traveled distance, the survey can be customized after inputting vehicle kilometerage.

- Using other model specifications.

- Optimum solution for problems like: most benefit of insurance companies, most decrease in car usage, most decrease in disobediences of law can be calculated.

\section{References}

[1] Islamic Parliament of Iran (1395) Mandatory Third Party Insurance Due to Automobile Damage Law.

[2] Vickrey, W. (1968) Automobile Accidents, Tort Law, Externalities, and Insurance: An Economist's Critique. Law and Contemporary Problems, 33, 464-487. https://doi.org/10.2307/1190938

[3] Edlin, A.S. (1999) Per-Mile Premiums for Auto Insurance. NPER Working Paper No. 6934, National Bureau of Economic Research (NBER).

[4] Hultkrantz, L., Nilsson, J.E. and Arvidsson, S. (2012) Voluntary Internalization of Speeding Externalities with Vehicle Insurance. Transportation Research Part A: Policy and Practice, 46, 926-937. https://doi.org/10.1016/j.tra.2012.02.011

[5] Wenzel, T. (1995) Analysis of National Pay-As-You-Drive Insurance Systems and Other Variable Driving Charges. Energy Analysis Program, Lawrence Berkeley National Laboratory-37321, Energy and Environment Division, University of California.

[6] Litman, T. (2012) Distance-Based Vehicle Insurance as a TDM Strategy. Victoria Transport Policy Institute. www.vtpi.org/dbvi.pdf

[7] Derikx, S., Reuver, M. and Koresen, M. (2016) Can Privacy Concerns for Insurance of Connected Cars Be Compensated? Electron Markets, 26, 73-81. https://doi.org/10.1016/j.tra.2012.02.011

[8] Zhao, X. and Zhou, X. (2014) Copula-Based Dependence between Frequency and Class in Car Insurance with Excess Zeros. Operation Research Letters, 42, 273-277. https://doi.org/10.1016/j.orl.2014.04.001

[9] Alshamsi, A.S. (2014) Predicting Car Insurance Policies Using Random Forest. 10th International Conference on Innovations in Information Technology, Al Ain, 9-11 November 2014, 128-132. https://doi.org/10.1109/innovations.2014.6987575

[10] Train, K. (2009) Discrete Choice Methods with Simulation. Cambridge University Press, Cambridge. https://doi.org/10.1017/CBO9780511805271 
Submit or recommend next manuscript to SCIRP and we will provide best service for you:

Accepting pre-submission inquiries through Email, Facebook, LinkedIn, Twitter, etc.

A wide selection of journals (inclusive of 9 subjects, more than 200 journals)

Providing 24-hour high-quality service

User-friendly online submission system

Fair and swift peer-review system

Efficient typesetting and proofreading procedure

Display of the result of downloads and visits, as well as the number of cited articles

Maximum dissemination of your research work

Submit your manuscript at: http://papersubmission.scirp.org/

Or contact gep@scirp.org 